\title{
Postcolonial Anxieties and the Browning \\ of New Zealand Rugby
}

\author{
Andrew D Grainger, Mark Falcous, \\ and Joshua I Newman
}

Looming large in dominant narratives of New Zealand's history is the "national sport," rugby union. ${ }^{1}$ The prominence of rugby in the forging of white-settler-Pākehā-narratives of nation has been well documented. ${ }^{2}$ As Simon During noted, rugby has been a particularly important social space for (apparently) reconciling the contradictory claims of the settler national imaginary-at once distinct from, yet connected to, the colonial center. Rugby union, During continued, emerged as a key "symbol of mateship, intrepidness, coloniser-colonised reconciliation. All this without the game losing its imperialist aura" $($ I998, 35). Premised as it was on masculine, heteronormative, often bourgeois, white settler-Pākehā values, rugby was thus a critical site for synthesizing competing narratives of European heritage and imperial ties with those of distinctiveness and settler fortitude and for asserting the benevolent success of the colonial endeavor at the outer edges of the British Empire (During 1985).

As James H Liu and his coauthors noted, New Zealand is a country in which "significant aspects of national identity are based on ideals of egalitarianism and lack of racism" (1999, I025). Accordingly, as an important cultural domain, discursive representations of rugby-from media commentaries to everyday public discourse-routinely assert ethnic diversity "on the pitch" as proof positive of successful assimilation, cooperation, and wider racial harmony beyond it (Belich 200I; MacLean I999; Phillips I987, I999; Hokowhitu 2009). Unlike colonial sporting stalwarts like cricket or soccer-sports that to this day maintain overrepresentations of Pākehā athletes at the elite levels of play-the genesis of these historically rooted mediations is often traced back to Māori players' on-field prominence starting as early as the mid-I870s; to their subsequent role

The Contemporary Pacific, Volume 24, Number 2, 267-295

(C) 2012 by University of Hawai'i Press 
as important, indeed prolific, international players; and to the presence of Māoritanga (Māori cultural elements) such as pre-match haka performed by the men's national team (the "All Blacks"). As James Belich noted, the Māori presence in rugby was "celebrated by Pākehā as solid evidence that the country was indeed a paradise of racial harmony" (200I, 209). Similarly, Jock Phillips contended that "people have not been slow to draw ... judgements about New Zealand as a racially harmonious society" from Māori involvement, particularly contributions to All Black successes ( 1987,286$){ }^{3}$ Notably, even today, and notwithstanding historical vicissitudes, ${ }^{4}$ rugby is still popularly rehearsed as emblematic of integration and tolerance.

The stridency with which the idea of rugby as a level racial playing field is defended was brought into focus in July 2002 through responses to newspaper columnist Chris Laidlaw's suggestions that New Zealand selectors at the time were favoring Pākehā over Māori and Pacific Islander players (Laidlaw 2002). ${ }^{5}$ Of the national side fielded a week prior, he wrote: "It was as Pakeha in complexion as New Zealand has possibly ever fielded ... this was essentially the All-Whites dressed in black." "The fact that [team selectors John] Mitchell and [Robbie] Deans have opted overwhelmingly for a Pakeha squad might be an accident and it might not," he continued. "I think not" (Laidlaw 2002). The comments, quickly dismissed by coaches, subsequently set off something of a media frenzy by New Zealand standards. An editorial in the nationally distributed New Zealand Herald reflected a defensive tenor, calling racism a "poisonous subject" and seeing it as "unfortunate that anyone has seen fit to question the racial make-up of an All Black team. Rugby in this country has never given it a thought. It is . . . offensive to all New Zealand that the question should even have been raised" (NZH 2002). Former players, coaches, and even opponents were also given voice to defend the idea of rugby's quixotic, color-blind credo in various media outlets. Overwhelmingly, their comments were consistent with the conservative denialism of the media, mirroring also the sentiments of the letters-to-the-editor majority who were provoked into rejecting Laidlaw's comments.

For our purposes, the substance of the anti-Laidlaw remonstrations are perhaps less important than how his commentary ultimately reinvigorated the popular myth of harmonious ethnic coexistence in rugby and the dominant narrative of sport as a world isolated from the profane realms of "race relations" within the postcolonial nation. ${ }^{6}$ The effects of Laidlaw's claims aside, what also interests us about this situation is that at 
the time he was writing — and indeed as would be the case now-an "all white" team would have seemed like a rather implausible occurrence. We mean this not in the sense of New Zealand rugby then or now being inexorably "multicultural." Rather, Laidlaw's allegations were made when the prevailing belief about rugby was instead that Pākehā men were fleeing the game in droves.

Only a few months earlier, the widely read New Zealand Rugby World magazine felt "white flight" in the sport to be such a phenomenon that in October 200I it was moved to ask (on its cover, no less) "Where Have All the White Players Gone?” Moreover, within weeks of Laidlaw's remarks, sports journalist Joseph Romanos delved into this "crisis" in his provocatively titled book The Judas Game: The Betrayal of New Zealand Rugby (Romanos 2002).7 According to the back cover, this book outlines how "the traditions, the values and the camaraderie that once made [New Zealand] rugby great have all been betrayed." One of the biggest issues for Romanos, though, was that "playing numbers are dropping dramatically" (2002, 24I) -nowhere more so than among the young. And the cause as he saw it? White flight.

That Laidlaw had reason to wonder "if some kind of Polynesian purge wasn't under way" seemed wholly at odds with what others saw as a "trend" (to use Romanos's term) toward rugby's "browning." A decade later, "white flight" in New Zealand rugby remains a far-from-dead issue. In just the past few years, for instance, "white flight" has received highprofile airings on the popular current affairs show Campbell Live (TV3 2007); in Time magazine (Williams 2008); and, most recently, on the popular program Deaker on Sport (2010).

In this article we interrogate the twinned discourses of "white flight" and the "browning" of, and in, New Zealand rugby. On one level, the apprehension surrounding white flight in New Zealand rugby could be viewed as merely stemming from the presumed threat to the "national game" posed by other sports, in particular soccer-a sport that has not only been, as one journalist put it, "riding the crest of a popular wave... in [a] rugby-mad country" during a much-ballyhooed World Cup campaign (Stutchbury 2010), but has also become New Zealand's most popular participation sport for children aged sixteen and under (New Zealand Football 2010). However, we argue that unease about the changing ethnic makeup of rugby in New Zealand more fundamentally belies a fear born of the prospect of the sport no longer being an exclusive preserve of Pākehā men. It is, first and foremost, an issue of race and ethnicity and 
the discomforting prospect for some of the nation being represented solely by Pacific Islander men. Borrowing from Ghassan Hage, we make the case that white-flight panic forms part of a broader "discourse of Anglo decline" (2000, I79). The protection of Pākehā whiteness-authored under the throes of a dominant postcolonial national mythscape-has long historical roots and reasserts itself in calls for tighter controls on immigration, resentment of so-called race-based political policies, and attempts to realign "New Zealandness" with the figure of the Antipodal European. In the process, we argue, rugby functions to re-center Pākehā whiteness at the core of a nation's racial politics and formations of cultural citizenship. Moreover, we point to the ways in which, through sport, bodies of difference-those "brown bodies" of Māori as well as those of people from islands such as Tonga, Sāmoa, and Fiji-are discursively constituted against the prevailing (Pākehā) national norm.

We suggest that the white-flight panic emerges precisely because the coproduction of race and space is never uncontested, and that Pākehā fears over the browning of rugby can hence be viewed less as a concern for the physical welfare of white boys than as a manifest vexation for the waning "managerial capacity" of Pākehā men over the national space (Hage $2000,42) .{ }^{8}$ It is our contention that, since the days of its colonial import, rugby in New Zealand has been marked out as the "natural" domain of white men-a domain where the "different" bodies of the Pacific Islander other, assumed to belong elsewhere, are, in a sense, "out of place" in the mythologized rugby spaces of the national imaginary (see Ahmed 2000). In this way, "Polynesian boys" are implicitly what Nirmal Puwar (2004) called "Space Invaders" who symbolically threaten the position of Pākehā men as "masters of national space" and their capacity to decide who stays in and who ought to be kept out of this space (Hage 2000, I7). We make our case by situating the popular manifestations of New Zealand's contemporary white-flight panic within broader postcolonial discursive and contextual formations, and we finish with a brief discussion of sport, cultural citizenship, and the politics of what George Lipsitz might refer to as the possessive investment in Pākehā whiteness (I998; see also Sullivan 2006).

\section{Multiculturalism in New Zealand}

At the level of demography, New Zealand is indeed a multicultural society, and shifts in immigration policy during the r 990 s have ushered in the 
formal deracialization of entry requirements, a move notably "couched in the rhetoric of 'enhancing New Zealand's multicultural society" (Pearson 2000, I04). Yet it is obvious that this civic, polyethnic conception of the nation does not always play well away from the glare of public scrutiny (Barber 2008). Moreover, it can be argued that as the nation is forced to reconcile its colonial past with its contemporary biculturalism(s), "new cultural racism(s)"-to borrow from Henry Giroux (I994)-have emerged and, with them, new postcolonial identity politics moored to old colonial power-knowledges (Fleras and Spoonley I999). As James H Liu and Duncan Mills noted, "New Zealanders are far less racially tolerant than their surface attitudes would lead an outside observer to believe" (2006, 9I). Supposedly egalitarian, New Zealand is as prone as anywhere to the malady of "modern racism," 9 characterized not by overt prejudice but by the way "traditional" (national) values work to conceal racial conservatism and racial hierarchization (Bonilla-Silva 2006).

Moreover, there is evidence to suggest that while "diversity" may be celebrated, it is defined and limited within the boundaries of a New Zealand national imagination that remains "Eurocentric, cemented together around a core of white traditions" (Schech and Haggis 2000, 236). In New Zealand, wrote David Pearson, "pluralistic rhetoric overlays a model of national development still driven by assimilationist imperatives ... [while] recent ethnic nationalism in New Zealand retains elements of deep-seated myths of origin that prefigure the shaping and reshaping of new destinies" (2000, I06). With this in mind, we turn our focus toward rugby. We do so with the understanding that rather than acting in isolation from these cultural politics, the "national game" has historically existed in dialectic cadence with the postcolonial race politics in New Zealand.

\section{Wounded White Boys and Sporting Melancholia}

Rugby, in this regard, represents a particularly salient domain with which critics should be concerned. Though on its surface rugby coalesces the multicultural, postcolonial present, it is also wrought with the multiple anxieties of a nation coming to grips with the ongoing unsettlement of a national imagination largely formulated in Pākehā terms. As anywhere, rugby is home to ethnic resentment and the defensive gestures of those who mourn the passing (illusion of) the unitary national collective. Following Paul Gilroy's discussion of "postcolonial melancholia" (2005), we suggest that rugby is symptomatic—and indeed constitutive—of an "anx- 
ious, melancholic mood" that has become part of this former colony's "cultural infrastructure" in recent times. In particular, we now examine the white-flight-panic discourse noted above as a means to demonstrate how constructions of race, nation, and ethnicity are entangled within the power relations of the postcolonial present. The melancholic tone of those troubled by the intersection of white flight and the "browning of rugby" cannot be separated "from that underlying hunger for reorientation" at the base of both antipathy toward immigrants and the unease that accompanies the (apparent) "minoritization of white culture" (Gilroy 2005, 90; Huggan 2007, 77). We go further in suggesting that this backward-looking search for cultural bearing through rugby is not simply a mirror of wider social disquiet-an outcome of material and symbolic processes or a hint as to national character-but is instead formative and productive of the very whitened, "rehomogenized national community" to which the white-flight panic appeals (Gilroy 2005, I09).

The enduring significance of Pākehā culture within rugby can most obviously be seen in anxious references to the supposed, and frequently unsubstantiated, decline in the number of "white boys" taking up the game: a preoccupation since the I990s and still a matter of unease for concerned commentators today. ${ }^{10}$ Here too we can see evidence of the penchant for the spatial ordering of the nation. Unease about white flight stems not only from white boys "turning their backs on rugby" (Paul 2004) but also from perceptions that their "place" is being taken up instead by their Māori and Polynesian counterparts. In a sporting space that has traditionally been a locus of colonial power, privilege, and identity, young white males are allegedly abandoning rugby while, in contrast, the number of Māori and Polynesian boys has (purportedly) undergone a dramatic increase. As one journalist recently put it, the rise of players of Pacific descent has coincided with "the dropout of less physically mature teenagers who have opted out of going up against the rookg plus [220-pound or more Pacific Islander] speed machines to avoid serious injury" (Malarski 2009).

The general theme among critics is that the pool of young white players in New Zealand is getting smaller and smaller every year while the rosters of some schoolboy teams, to borrow a phrase from one rugby administrator, now "read like passenger lists from Polynesian Airlines" 11 (quoted in Romanos 2002, I73). The picture painted is one of young Polynesians coming to dominate rugby to such an extent "that many curtainraisers ... rarely feature a white player" (Deaker I998, I62). "When I go to rugby grounds on a Saturday morning" lamented Romanos, "the per- 
centage of Polynesian and Māori boys playing is striking. In some teams, the odd white boy stands out as being different" (Romanos 2002, I77). So dramatic is the changing face of rugby that in Laidlaw's eyes "a page in New Zealand's sporting evolution is being rapidly turned." "The 2Ist century," he explained, "will be an age in which [rugby] will be dominated by young Polynesians" (Laidlaw I999, I 83).

One of the more pressing issues for these writers is that the "problem" extends beyond the junior ranks (Paul 2004). Many are convinced that a similar "transformation is well under way" at the professional level (Laidlaw I999, I 83). Certainly, there is some basis for suggesting that the player makeup of elite rugby in New Zealand is "browning." Little more than ten years ago, there were 25 players of Pacific Islander descent contracted to play for New Zealand's "Super Rugby" franchises. In 2008, 43 of the I 40 contracted players in the expanded Super I 4 competition were of Pacific heritage (Malarski 2009). In New Zealand's largest city, Auckland, around 9,000 of the roughly 21,000 registered club rugby players were classified as "Pacific peoples" in 2007, making them the most represented ethnic group. The figures are even more dramatic for the wider Auckland region, wherein Pacific peoples accounted for almost 60 percent of all players aged $\mathrm{I} 2$ and over and almost 70 percent of those playing senior rugby in 2007 (Paul 2007). The inevitable concern for anxious observers is where these changes may lead: the prospect that there could possibly come a day when the All Blacks "no longer feature a single white face" (Laidlaw I999, I83). Doubtless they would find little comfort from one local rugby scribe who posited that such is "the growing dominance of Polynesian athletes" that "it's not inconceivable that come the 20 I I World Cup, New Zealand as hosts kick-off the first game with a matchday 22 that consists solely of players who come from a Pacific Island background" (Paul 2007).

For those uncomfortable with such a prospect, white flight presents an apparently obvious factor to blame. The diminishing prominence of Pākehā males in New Zealand rugby begins, so it is surmised, in the junior ranks, where "white numbers are falling," and as such it augurs the "disappearance from the All Black team of all but a few token white players" (Jones, 2004). In examining the discourse surrounding white flight, a particularly interesting feature of this focus on youth is the way in which the "Polynesian predominance" (NZH 2004a) affords the opportunity to turn New Zealand's racial hierarchy on its head so that-to relocate Kyle Kusz's description of a similar white backlash in the United States-Pākehā 
"can be positioned as a seemingly legitimate unprivileged subject" (Kusz 2007, 99; emphasis added). In essence, young Pākehā boys are positioned as "victims." The overwhelming success of Polynesian males in both the junior and senior ranks is framed as an exclusionary force that constrains possibilities for Pākehā boys. Daniel Williams, for instance, writing in Time magazine, posited the rise in Polynesian participation as one reason "for the flight from the game of large numbers of comparatively slight [read white] boys" $(2008,40)$. Surveying the junior rugby scene, Laidlaw similarly wrote: "All over the country the pattern is repeating itself. More and more school and age group teams are reliant on youthful Polynesian vigour to make the difference. Hulking youngsters dominate the landscape at almost every game. Fifteen year olds weighing a hundred kilos, and playing centre, have become the norm. It is an arresting sight, not least for the modestly proportioned Pakeha lads who get run over every Saturday and wonder how many more times they must be offered up as a human sacrifice. As a parent-spectator I have found myself wincing on the sideline as the footsoldiers of mainly Pakeha teams are comprehensively flattened by the heavy armour of their mainly Polynesian opponents" (I999, I82).

In this and other media outputs, Pākehā boys are often mediated as though they are suffering at the hands of the Polynesian counterparts. Out of these media and lived tensions around the racial politics of rugby, we see rugby situated squarely in the crosshairs of national bicultural anxieties (and particularly of the victimized and vulnerable young Pākehā male).

Polynesian players' dominance is taken as "naturally" conferred through their apparent advantages in physical development. By way of example, Williams offered that "most people involved in rugby ... will tell you that Polynesians are naturally suited to the [sport]" (2008, 42; our emphasis). He wrote of how "it would be hard to find anyone who would dispute that Polynesian kids grow fast. In football, this means they tend to be bigger than their white peers" (Williams 2008, 42). This "natural" line of reasoning is perhaps the most frequent and widely promulgated with regard to white flight. As John Matheson confidently asserted, "Without question, the most common reason [for white flight] is that the young white athlete is intimidated by the growing number of Polynesians playing the sport" (200I, 2I). Demonstrating the degree to which the argument is taken as common sense, Romanos suggested that "You do not need to be a scientist to know that an eight-year-old, I 2-year-old or I 5-year-old Polynesian boy will almost inevitably be much bigger than a white boy the same age" (2002, I7I). Or as one club coach colorfully put it, "It gener- 
ally comes back to one thing-the sheer athletic ability of the Polynesian versus the European. A I4-year-old Polynesian will almost always shit all over the white kid" (quoted in Matheson 200I). It is thus the size of Pacific Islanders that is driving white boys away from the sport.

While we take issue with the naturalization of racial athletic aptitudes, given our present scope, readers are pointed elsewhere for further discussion (Hokowhitu 2004, 2005; Hokowhitu and Scherer 2008). For now it is perhaps enough for our objectives to note that it is, for all intents and purposes, taken as a truism that Polynesian boys are more "physically developed" and thus better suited for a game that requires physicality, aggression, and strength. As the Auckland Rugby CEO David White is quoted as saying, "Whether we like it or not, Polynesian kids mature physically earlier, they're big and strong and we can't hide from that" (quoted in Thomas 2003, I33). The veracity of such contentions is all but assumed-or as one former All Black put it, "undeniable." Such views ominously construct a racially deterministic argument that evokes "assumptions about the violent, powerful, but 'nobly savage" Polynesian (Brabazon 2006, I84) - a line of reasoning of little veracity but heavy consequence (see Brislin 2003; Hokowhitu 2003a, 2003 b, 2004, 2005, 2008; Jolly 2008).

Setting aside momentarily the way the success of Polynesian players is attributed to innate or instinctive "qualities," however, it is interesting to note the way young white males are figured as having their agency constrained. To some, the development of white boys is stunted by what, in John Hoberman's view, can be described as a "racial inferiority complex" (I997, 6). Apparently, white boys have simply given up. "There are reports," wrote Laidlaw, "of some talented, but physically intimidated young Pakeha players growing dispirited by these disparities in size and firepower and giving the game away" (I999, I82). According to Romanos, these players are "sick of having the daylights knocked out of them by boys who have such physical advantages" (2002, I9). One coach similarly despaired of the decision facing Pākehā boys: "Look at the choice he has. The young white kid can say to himself, 'I am a skinny little kid. I am I 3 years old. I can go and play with my skateboard or I can go and run against that $80 \mathrm{~kg}$ Polynesian guy and get absolutely hammered.' Why would he want to play rugby?" (quoted in Romanos 2002, I7I). These physical advantages are seen to be exacerbated by a "Polynesian style" of play that exploits these "natural" differences in size (Grainger 2009). According to onetime All Black Norm Hewitt, "the Island boys all look 
up to [players like] Jonah Lomu, and they want to play like him. ${ }^{12}$ They get the ball and want to run over their opposition"- - the opposition being, in his words, "little white boys, who are about half as big" (quoted in Romanos 2002, I77). Again, this reaffirms the idea of an "innate" style of play, the abilities for which, like their size, Polynesian boys are handed on a "genetic plate" (Hokowhitu 2003a, 2I2). In doing so, this discourse affirms the belief that Polynesian domination on the field is due to physicality. Other attributes of success in rugby-tenacity, determination, and tactical skills-are, in a hierarchically racialized formulation, absent from the explanations.

On the surface, then, the white-flight crisis appeals to neutrality by rendering Polynesian boys as naturally different, naturally bigger, and thus naturally a threat to their Pākehā counterparts. That these differences are natural is important because it normalizes the white-flight-panic discourse, permitting statements that might otherwise be interpreted as racially motivated. One is reminded here of Eduardo Bonilla-Silva's implication of such "color-blind" rhetoric in the production and reinforcement of the status quo (2006). Of particular note is the way "color-blind" racism can function through a naturalization "frame of reference"- the "set path for interpreting information"-that Bonilla-Silva asserted "allow[s] whites to explain away racial phenomena by suggesting they are natural occurrences" $(2006,28)$. We could perhaps propose that this is typical of new (or modern or symbolic) racism generally in that it is a process and an ideology of naturalization, of constructing social relations as natural and unchangeable. As Vincent F Rocchio contended, appeals to nature, or the natural state of things, are "popular mode[s] of rhetoric for maintaining the status quo of inequality and its modes of categorized oppression" $(2000,75)$. Rhetorically, the strategy works by making frequent recourse to phrases such as "that's the way it is"-something that normalizes what is spoken. We see evidence of such techniques in the white-flight-panic discourse. Romanos, for instance, argued that racism is a nonfactor when it comes to explaining white flight. "[Racism] is not the case at all," he wrote. "What happens is that boys, and their parents, are intimidated by the size of the Māori and, particularly, the Polynesian boys of the same age" (Romanos 2002, I70). Laidlaw similarly chastised the "dedicated schools of politically correct thought that insist that we are all the same. We aren't, and it couldn't be more obvious when an ethnically mixed bunch of early teenagers take the field" (I999, I 82). Racism is thus disavowed: the fear is based in biology-Polynesian boys are naturally a threat. 
Despite these claims to the contrary, race sits at the center of the whiteflight-panic discourse-even if never acknowledged. However, we can only see this by implicating the white-flight debate in wider discourses about the declining position of white males in New Zealand rugby and the nation more generally. To borrow from Paul Thomas (in one of the more astute commentaries regarding white flight), it seems reasonable to ask whether it is " just a roundabout, mealy-mouthed way of expressing alarm over the browning of the game and specifically the All Blacks" (2003, I35). Farah Palmer observed how "there is a common perception among sports followers and sports media that Māori and Polynesian athletes are dominating [New Zealand's] high-profile and elite sports teams" (2007, 3II).

In addition to a string of articles in the press, two documentaries have visited the issue. One, titled The Brown Factor (2004), skews toward the decidedly romantic in its take on the place of Māori and Pacific Islanders in New Zealand rugby and rugby league: those surveyed almost exclusively proffer the sports as having had a positive impact on race relations. As one pundit, barrister Kahungunu Barron-Afeaki, asserted in the program, "Sport, particularly professional sport, has broken down more racial barriers than anything else put together." The program is also notable for the way it repeats dominant race ideologies that attribute the success of Polynesians to their inherent physicality. This, however, was even more explicit in the second documentary, Polyunsaturated (cited in Grainger 2008, I35). In brief, the program is strikingly reminiscent of the infamous 1989 NBC News feature Black Athletes: Fact and Fiction in the way it sets out to discover "the physical reasons for the Polynesian superiority in rugby" (1989; see also Davis I990). It states from the outset that Polynesian players "are faster and stronger than Pākehā."

Like The Brown Factor, it also takes as given that the "browning of New Zealand rugby" is a known fact. The "proof" offered is usually of the type of circumstantial evidence we discussed earlier: the number of recent All Blacks of Pacific heritage, the rising proportion of Māori and Pacific peoples in professional rugby, and the alleged "exodus" of "large numbers of comparatively slight [read white] boys" from junior rugby (Williams 2008, 40). More frequently, however, the evidence is anecdotal, the seldom backed-up observations of coaches, administrators, media pundits, and fans. Similar to discussions of its presumed causes and effects, the reality of white flight seems also to require little substantiation. The sports radio and television talk show host Murray Deaker, 
for instance, considered white flight to be "very real" pointing only to his own observations during "years on the sidelines." ${ }^{13}$ From his vantage point, Deaker saw "a minute number of Europeans playing senior club rugby and a drop off in the numbers coming in at lower levels"-neither of which he substantiated (quoted in Romanos 2002, 80). Romanos equally alleged "white players" to be "in a small minority in terms of senior rugby" (2002, I8I). He based this contention on his observation of senior rugby in Auckland, neatly sidestepping the fact that two-thirds of New Zealand's 265,974 Pacific peoples live in the Auckland Region (Statistics New Zealand 20I0a, 20Iob). It is hardly, then, a representative sample of "New Zealand" rugby. That a recent survey of adult participation numbers found that Pākehā account for over 50 percent of all rugby players and outnumber Pacific peoples by over 3 to I also runs counter to the notion of there being any "brown takeover" of New Zealand rugby (SPARC 2009; SST 2003).

Though we would argue that the case in agreement is overstated, our point here is not to enter into the debate about whether the browning of rugby is actually happening. More pertinently, we suggest that, happening or not, the browning of New Zealand rugby is perceived as real. More significantly, browning is not only taken as a given but also felt to be problematic-and it is certainly treated in discourse as such. Interesting in this regard is that the reason why either browning or white flight should be cause for concern is never clearly articulated in treatments of these issues. However, it is difficult to deny that race-based anxiety plays a part and that racial prejudice, however latent, is a feature of the discourse. An evident case in point is the scapegoating of Pacific Islander players. A number of observers have proffered the "influence of Pacific Island[ers]" as one of the reasons why, despite dominating the game, the All Blacks have consistently failed to win the Rugby World Cup since 1987 (Malarski 2009; see also Paul 2009). In précis, their arguments appeal to the banal stereotype of the "natural physical strength and superior skill" of Māori and Pacific Islander players "being diluted by lack of discipline and ability to concentrate" (Ropati 2006, 20). An example of this-inherently ideological and highly problematic (see Hokowhitu 2004) - type of "naturalized" or "common sense" discourse is the suggestion that New Zealand has won the World Cup just twice in seven attempts because the "development of Pacific power" has left the All Blacks without "enough strong decision-makers on the field" (Malarski 2009). Though overt prejudice may be veiled by the seeming neutrality of the "quasi-Social Darwinism" 
employed here (Hokowhitu $2003 \mathrm{~b}, 23$ ), it offers insight into some of the ways in which latent racism and ethnic enmity underpin public discussions of the place of Pacific people in New Zealand rugby.

The racially tinged nature of the discourse is also apparent in the sullen dissatisfaction of some critics in regard to the potential symbolic repercussions of rugby's browning. Echoed elsewhere, comments by Romanos (2002) and Deaker (1998) are illustrative here. For instance, in a revealing summation of his concerns Romanos wrote: "The All Blacks have always represented New Zealand; they are the sports team that New Zealanders have identified with. I wonder if all New Zealanders still feel that the All Blacks are representative of New Zealand in general, when half of them (sometimes more) are brown-skinned. Where are we going with this? Will New Zealand rugby at national and international level comprise of a group of brown-skinned players playing, being cheered on by white spectators and television viewers?" (Romanos 2002 quoted in Grainger 2008, I37).

Deaker seemed similarly apprehensive about the prospect of New Zealand rugby coming to "emulate the United States where so much of their televised sport seems to feature wonderfully skilled black athletes competing while whites make up the bulk of the spectators" (I998, I62). He consequently argued that "somehow young white players have to be encouraged to remain in the game if rugby is to truly remain our national sport.... Pakeha kids aged fifteen to twenty must be positively assisted to stick with it at an age where they are getting belted over by more mature Polynesians" (Deaker I998, I62).

\section{Corporatized Rugby Versus (PĀKehā) Myths of Rural Idyll}

There is an interesting slant to ways in which those statements mourning the waning dominance of Pākehā in rugby intersects with local fears about the accelerating commercialization of the game-particularly since its professionalization in 1995. With "Americanization" and "commercialization" frequently taken as synonymous in the world of sport (Fort and Fizel 2004; Miller, Lawrence, and Rowe 200I), reorganization along commercial lines has led to a current of popular opinion that rugby has, to its detriment, become "Americanized." Any further resemblances to "American sport" may thus exacerbate such concerns. In Romanos's and Deaker's view, the game divided-between brown players and a white 
audience—is an "Americanized" game, purportedly anathema to All Black history and the team's role as New Zealand's most prominent cultural ambassadors. In this way, a parochialized, if not recolonized, idealized rugby archetype is set in contrast to the (imagined) racially divisive, overcommercialized nature of sport in the United States. Romanos concluded his argument by suggesting that in the age of commercialism and professionalism, corporate entities might likely flee from rugby sponsorship if the trends toward a "browning" of New Zealand rugby continue. Evoking a twisted corporatist-paternalistic logic, he argued that a losing All Black team overrepresented by Māori and Pacific Islander players would not appeal to the potential business entity seeking to root itself to the local community-in this case presumably the abstract, parochial, white community that Romanos believed defines the nation.

But there is also a clear cultural investment in the politics of collective racial memory here. In this regard, we suggest first that the "nationalist imaginary" (see Hage 2003) invokes the regulatory structure of-as we argue below, rural-whiteness; and second that, as a consequence, the conspicuous presence of Pacific peoples represents a disruption of the enduring circulation of whiteness as the source of national representation. Initially, we should note that any anxiety about the Americanization of New Zealand rugby has a lot to do with concerns as to how professionalism and commercialization are affecting the players themselves (Knight 2007; Laidlaw 20I0; Ryan 2005, 2008; Taylor 2007). Though more prevalent when their performances fail to meet public hopes and expectations, modern All Blacks, as Wayne Hope observed, are frequently "deemed to be professional yet pampered, athletically skilled yet robotic, individually committed yet passionless as a team" (2002, 235). As Adrian Smith described it, conservative critics argue that more recent All Black teams lack "the physical and mental strength embodied by previous generations of countrybred 'hard men'" (2004, I8 5; see also Phillips I 999). Likewise, Greg Ryan noted how, following New Zealand's recent World Cup failures, it has become commonplace among the nostalgia-prone to lament the passing of "high-profile forwards from farming backgrounds such as Colin Meads, Brian Lochore and Ian Kirkpatrick-men who epitomised the qualities of toughness and dedication that the [modern] All Blacks generation of 'soft' and 'pampered' All Blacks had apparently lost" (2005, I 5 I-I 52 ).

Here, both Smith and Ryan constructively linked the idealized history of rugby to a "rural myth" (see also Phillips I987; Ryan 200I, 2008; Smith 2004) whereby "the emergence, growth and early success of New Zealand 
rugby has been attributed to the exploits of pioneer farmers and the fabric of rural society generally" (Ryan 2005, I 52). According to this imagined narrative, rural rugby produced "hard men," in contrast to "the urban environment of softness, easy living and pampered decadence-a world apparently inhabited by contemporary All Blacks" (Ryan 2005, I 54-I 55 ). Building on this argument, we suggest that this longing for the rural "heartland" is a nostalgic pining for the "good old days" when the centrality of European (British) settler men was established within the national imaginary. The reaffirmation of rugby's rural mythology is a critique not just of urbanism per se but also of urban multiculturalism (Smith 2004).

In New Zealand, we cannot ignore the interconnection between rurality and whiteness. ${ }^{14}$ In particular, the ethnic Other is regularly rendered as subordinate within visions of pastoralism and rurality. As Brendan Hokowhitu noted (2004), the ruling and cultivating of the land by Pākehā included the "taming" of the native population. The sequestration and occupation of land was critical to the extraction of wealth that was central to colonialism and the foundation of the "racialised" discourses of New Zealand nationalism that privileged "whiteness." Yet whiteness is not a universal, monolithic structure of power without contextual nuance. As Suvendrini Perera cautioned, it should be seen as "a series of investments and interests unevenly inflected by factors such as class, ethnicity and gender" (I999, I 84). Thus, these formations of ethnogenesis-the construction of settler identities as distinct from colonial origins-bound to Pākehā cultures, rural life, and the land become activated and authorized through discursive acts.

Claudia Bell noted the role of "kiwiana"-the artifacts and images privileged as symbols of nation-in the production and active construction of the collective Pākehā "national" imagination. As she noted, these frequently valorize "simple" and "honest" symbols of rurality—such as unpeopled landscapes, the bach (holiday home), farming paraphernalia, and pragmatic values. The result is the creation of a "fictive cultural history, one that is plainly Pākehā dominated"; kiwiana, she noted "reasserts Pakeha primacy" (2004, I75). Romantic, liturgical visions of rural rugby in contemporary New Zealand culture abound. These emphasize discourses of communal unification and of a "grassroots," unsophisticated, noncommercial (ie, amateur), national sporting condition: elements that we argue are commonly reified in these forms of kiwiana. This is further evidenced in rugby contexts through Mark Falcous and Alan West's identification of the romantic and conservative idealization of rural mas- 
culinity that emerged in the New Zealand press surrounding the 2005 British Lions tour (2009). As they noted, such constructions "feed into longstanding myths which romanticize and elevate the importance of rural—specifically Pākehā-settler masculinity" (Falcous and West 2009, I64). Such romantic versions of rugby play against the fears of the new, corporatized, media-dominated, professionalized, urban-centered, and indeed "browned" game. As Avril Bell affirmed, "assertions of cultural identity are also linked to political claims and material struggles" (I996, I46). Such images, then, are neither benign nor innocent in their evocations. They also eradicate the historical struggles surrounding rugby: seeking to mask the exclusions, imperial loyalties, brutish masculinities, and misogyny that render the game politically and socially malignant.

In spatial terms, these national stories and constructions of belonging are based on racialized and exclusionary foundations wherein the rural is framed as the site of national (white) authenticity while the city becomes a site of miscegenation where national values and identities are compromised by ethnic and cultural diversity—by what Jon Binnie and his coauthors described as an emergent "cosmopolitan urbanism" (2006, I; see also Chakraborti and Garland 2004; Cloke 2004; Cook and Phillips 2005; Neal and Agyeman 2006). Tellingly, Ryan's examples of the much-romanticized heartland "farmer/All Black" that we mentioned earlier are all Pākehā. A prominent local broadcaster's take on the state of New Zealand rugby similarly intimated at how popular perceptions of rurality indirectly safeguard the racialized boundaries of both rugby and the nation: "I think it's fantastic that we have [Pacific people, and] that can help us develop our sport ... But I also want the hard, tough white farmer to be a part of my All Blacks side ... there for 80 minutes in a ruthless uncompromising way" (quoted in Matheson 200I, 32). As such, these comments and those cited earlier demonstrate that the rugby myth is clearly based on discourses of national exclusion in which rurality and whiteness are key elements.

The obviously Pākehā speaker also highlighted an important rhetorical device through which such exclusions are achieved. The use of the possessive "our," as in "our sport," unequivocally reads here not only as implying national ownership, but white ownership: "our" creates a distance between Pākehā, who "own" the national game, and Pacific people, who merely contribute to it. The statement echoes what Hage aptly described as a "discourse of cultural enrichment" that valorizes the place of "ethnic" cultures while simultaneously placing whiteness at the center of the 
national cultural map $(2000,23)$. The much-mythologized Pākehā rugby player not only provides a link to a rural, idyllic New Zealand past, but also, in the association of rurality with whiteness, simultaneously claims rugby as a space of Pākehā authority. The coupling of rugby and rurality acts as a nostalgic device by which Pākehā are able to reassert the whiteness of the national imaginary when such synonymity is otherwise challenged by biculturalism and cultural diversity. Hence, through the recolonization of history—via lionized embodiments of the pastoral, pioneering sporting exemplar-rugby rhetoric becomes a significant link to colonial power structures and colonial whiteness on which dominant readings of the nation can be forged, proliferated, and reproduced. For most Pākehā, their imagining of national space is no longer congruent with their actual experiences of lived spaces that are instead increasingly multicultural. Rugby's past, in being imagined as bounded and homogeneous, in turn provides a degree of security for discontent Pākehā in that identity is tied to, and ties, whiteness and the nation.

\section{Conclusions}

The twinned "browning" of rugby and "white flight" debates that we have interrogated are notable in that they pivot around the junction of several intersecting discourses: one of (fears of) white decline in the face of change, a reactionary wistful nostalgia for the apparent political, economic, and cultural certainties of the past; of rugby as previously unsullied by commerce and/or "browning"; and of myths of rurality that counteract the threatening urban, multicultural present (see Cosgrove and Bruce 2005). Thus they are the product of a unique conjunctural moment and intersecting contexts. Within public discourse, "browning" is both problematized and apparently celebrated with ambiguous, decontextualized pronouncements that go unexplored by the media.

The "browning" and "white-flight" panics occur simultaneously with the emergence of a broader polarizing political moment alongside broad shifts in the structure, ethos, and organization of rugby. The changing face of rugby fundamentally alters the sociopolitical certainties that colonialist discourses have prescribed for it (see Falcous 2007). In this broader state of flux, Hokowhitu noted the context of ongoing challenges to white privilege by Māori and the ensuing right-wing backlash that asserts that white New Zealanders are victims of "reverse racism." As a sporting manifestation of this, he has documented the "reconfiguring of the Māori All Blacks 
as a cultural text" during the early 2000 (2009, 2327). Specifically, he detailed the (re)framing of the exclusively Māori team by white commentators as symptomatic of an unfair Māori privilege. Relatedly, as Andrew Grainger detailed (2006), the late I990s and beyond saw the increasing presence, indeed overrepresentation of Pacific Islander players in the elite echelons of New Zealand rugby, including the national team. The trend reached its apogee with the appointment of Jonathan Ionatana Falefasa "Tana" Umaga the first New Zealander of Pacific heritage to captain the All Blacks. In the discourses surrounding the rise of Pacific Islander players, and notwithstanding the ostensible signs of racial progressiveness signaled by this phenomenon, Grainger was able to discern the hegemonic and exclusionary notions of nationality that circulate in popular discourse surrounding "Polynesian" rugby players in New Zealand (2006).

What is notable about the browning debates is an intersecting ambiguity that fuses Māori and Pacific Islander players together as a collective threat, thus conjoining alternate histories, identities, and contexts to constitute "brownness" as distinct from Pākehā whiteness. Critically, distinctions remain unspoken in public discourse, and hence ambiguity remains. Furthermore, it is important to note that the browning debates do not merely reflect wider struggles and polarizations of cultural citizenship (see Larner 2006), but also actively construct them in potent, emotive, and highly visible ways through the high-profile national context of rugby.

THIS COAUTHORED ARTICLE represents a substantially revised, updated, and more developed version of Grainger 2008, chapter 2.

\section{Notes}

I In the title and throughout the article, we purposefully use the name "New Zealand" as opposed to "Aotearoa" in order to locate the name within a Eurocentric—or more accurately a white-centered—national imaginary, which we seek to problematize.

2 Crawford 1985; Fougere 1989; Haynes 1996; Hokowhitu 2003a, 2003b, 2005, 2009; Hope 2002; MacLean I999; Phillips I987, I999; Ryan 2005.

3 In this sense, Phillips's general point is that, alongside Pākehā-Māori contributions in war (specifically World War I), rugby was a key domain that asserted a cohesive national collective. 
4 The tour of a "Springbok" team representative of apartheid South Africa in I98 I, which featured wide-scale protests and violent disorder, is the foremost example of the racially divisive aspect of the game being explicit in public discourse around rugby. Domestically, protest surrounded the exclusion of Māori players from "all black" tours to racist South Africa in I960.

5 Laidlaw is the former All Black who in I 973 published an unusually insightful book, Mud in Your Eye, with reflections on rugby. He has subsequently been a Labour member of Parliament and is now a journalist. He is a frequent public voice on rugby issues.

6 As an anonymous reviewer pointed out, it is worth noting that Laidlaw's accusations are not implausible in the context of the deeply entrenched racialization of players' potential-qualities that could result in positional segregation, or "stacking" on the basis of deeply rooted beliefs among selectors and coaches.

7 Romanos is a frequent contributor to New Zealand media focusing on sports issues.

8 Indeed, New Zealand rugby-like rugby in most Southern Hemisphere nations-has a long history of white male overrepresentation in on-the-field and administrative managerial positions.

9 Augoustinos, Tuffin, and Every 2005; Barker I98I; McConahay I986; McConahay, Hardee, and Batts I98 I; Merenstein 2008.

Io For example, Burdon 2002; Coffey 2004; Deaker I998; Hands 2003; Hyde I993; Laidlaw I999, 20I0; Malarski 2009; Matheson 200I; Newton 2009; NZH 2004a, 2004b; Paul 2004, 2007, 2009; Romanos 2002; Souster 200I; SST 2003; Thomas 2003; Welham 2006; Williams 2001, 2008.

I I Polynesian Airlines is the now defunct international arm of the national airline of Sāmoa.

I 2 Jonah Lomu is a famed All Black of Tongan heritage.

I3 Deaker is a prominent national rugby journalist, who hosts national radio phone-in shows and television discussion shows. His tenor is as a "hard-hitting" provocateur asking the "hard questions." Much of his framing resonates with a reactionary crisis discourse that seeks to protect "the game" from apparently contaminating forces such as media and corporate marketers. As such, it pivots on a romanticized perception of the game (see Falcous 2007).

I4 Bell I996, I997, 2004; Berg and Kearns I996; Dominy I995, 200 I; Liepins 2000; Panelli and others 2008; Panelli and others 2009; Woods 2005.

\section{References}

Ahmed, Sara

2000 Strange Encounters: Embodied Others in Post-Coloniality. London: Routledge. 
Augoustinos, Martha, Keith Tuffin, and Danielle Every

2005 New Racism, Meritocracy and Individualism: Constraining Affirmative Action in Education. Discourse and Society I 6 (3): 3 I 5-340.

Barber, Keith

2008 "Indigenous Rights" or "Racial Privileges": The Rhetoric of "Race" in New Zealand Politics. The Asia Pacific Journal of Anthropology

Barker, Martin 9 (2): I4I-I 56.

I98 I The New Racism: Conservatives and the Ideology of the Tribe. London: Junction Books.

Belich, James

200I Paradise Reforged: A History of the New Zealanders from the I $880 \mathrm{~s}$ to the Year 2000. Honolulu: University of Hawai'i Press.

Bell, Avril

I996 “We're Just New Zealanders": Pakeha Identity Politics. In Nga Patai: Racism and Ethnic Relations in Aotearoa/New Zealand, edited by Paul Spoonley, David Pearson, and Cluny Macpherson, I44-I 58. Palmerston North, NZ: Dunmore Press.

Bell, Claudia

I996 Inventing New Zealand: Everyday Myths of Pakeha Identity. Auckland: Penguin.

I997 The "Real" New Zealand: Rural Mythologies Perpetuated and Commodified. The Social Science Journal 34 (2): I45-I 58.

2004 Kiwiana Revisited. In Cultural Studies in Aotearoa New Zealand: Identity, Space and Place, edited by Claudia Bell and Steve Matthewman, I75-I 87. Oxford, UK: Oxford University Press.

Berg, Lawrence D, and Robin A Kearns

I996 Naming as Norming: "Race," Gender, and the Identity Politics of Naming Places in Aotearoa/New Zealand. Environment and Planning D: Society and Space I4:99-I 22.

Binnie, Jon, Julian Holloway, Steve Millington, and Craig Young

2006 Introduction: Grounding Cosmopolitan Urbanism: Approaches, Practices and Policies. In Cosmopolitan Urbanism, edited by Jon Binnie, Julian Holloway, Steve Millington, and Craig Young, I-34. New York: Routledge.

Black Athletes: Fact and Fiction

I989 First broadcast 25 April on NBC television. Presented by Tom Brokaw and Jon Entine and produced by Jon Entine.

Bonilla-Silva, Eduardo

2006 Racism Without Racists: Color-Blind Racism and the Persistence of Racial Inequality in the United States. 2nd edition. Lanham, MD: Rowman \& Littlefield. 
Brabazon, Tara

2006 Playing on the Periphery: Sport, Identity and Memory. New York: Routledge.

Brislin, Tom

2003 Exotics, Erotics, and Coconuts: Stereotypes of Pacific Islanders. In Images that Injure: Pictorial Stereotypes in the Media, and edition, edited by Paul M Lester and Susan Dente Ross, I03-I I I. Westport, Ст: Praeger.

The Brown Factor

2004 First broadcast I 5 November on TV One. Produced by Kay Ellmers and directed by Te Kauhoe Wano.

Burdon, Nathan

2002 Flair Doesn't Win Trophies. Southland Times (Invercargill, NZ daily), I I July.

Chakraborti, Neil, and Jon Garland, editors

2004 Rural Racism. Cullompton, uk: Willan Publishing.

Cloke, Paul

2004 Rurality and Racialised Others: Out of Place in the Countryside? In

Rural Racism, edited by Neil Chakraborti and Jon Garland, I7-35.

Portland, OR: Willan Publishing.

Coffey, John

2004 Ill-Informed, Like Wally from Wagga Wagga. The Press (Christchurch daily), 5 March.

Cook, David, and Martin Phillips

2005 People in a Marginal Periphery. In Contested Worlds: An Introduction to Human Geography, edited by Martin Phillips, 353-402. Aldershot, uk: Ashgate.

Cosgrove, Amanda, and Toni Bruce

2005 "The Way New Zealanders Would Like to See Themselves": Reading White Masculinity Via Media Coverage of the Death of Sir Peter Blake. Sociology of Sport Journal 22 (3): 336-355.

Crawford, Scott A G M

I985 The Game of Glory and Hard Knocks: A Study of the Interpenetration of Rugby and New Zealand Society. Journal of Popular Culture I9 (2): 77-9I.

Davis, Laurel R

I990 The Articulation of Difference: White Preoccupation with the Question of Racially Linked Genetic Differences Among Athletes. Sociology of Sport Journal 7 (2): I79-I 87.

Deaker, Murray

I998 The Man in the Glass: An Autobiography. Auckland: Hodder Moa Beckett. 
Deaker on Sport

$2010 \quad$ First broadcast on 23 March by SkySports. Presented and produced by Murray Deaker.

Dominy, Michèle D

I995 White Settler Assertions of Native Status. American Ethnologist 22 (2): $358-374$.

$200 \mathrm{I}$ Calling the Station Home: Place and Identity in New Zealand's High Country. Lanham, MD: Rowman \& Littlefield.

During, Simon

I985 Postmodernism or Postcolonialism? Landfall 39 (2): 366-380.

I998 Postcolonialism and Globalisation: A Dialectical Relation After All? Postcolonial Studies I (I): 3 I-47.

Falcous, Mark

2007 The Decolonizing National Imaginary: Promotional Media Constructions During the 2005 Lions Tour of Aotearoa New Zealand. Journal of Sport and Social Issues 3 I (4): 374-393.

Falcous, Mark, and Alan West

2009 Press Narratives of Nation During the 2005 Lions Tour of AotearoaNew Zealand. Sport in Society I 2 (2): I 56-I 73.

Fleras, Augie, and Paul Spoonley

I999 Recalling Aotearoa: Indigenous Politics and Ethnic Relations in New Zealand. London: Oxford University Press.

Fort, Rodney D, and John Fizel

2004 International Sports Economics Comparisons. Westport: Praeger.

Fougere, Geoff

I989 Sport, Culture and Identity: The Case of Rugby Football. In Culture and Identity in New Zealand, edited by David Novitz and William E Willmott, I IO-I22. Wellington, NZ: GP Books.

Gilroy, Paul

2005 Postcolonial Melancholia. New York: Columbia University Press.

Giroux, Henry A

I994 Living Dangerously: Identity Politics and the New Cultural Racism. In Between Borders: Pedagogy and the Politics of Cultural Studies, edited by Henry A Giroux and Peter McLaren, 29-55. New York: Routledge.

Grainger, Andrew D

2006 From Immigrant to Overstayer: Samoan Identity, Rugby, and Cultural Politics of Race and Nation in Aotearoa. Journal of Sport and Social Issues 30 (I): 45-6I.

2008 The Browning of the All Blacks: Pacific Peoples, Rugby, and the Cultural Politics of Identity in New Zealand. PhD dissertation, University of Maryland, College Park. 
2009 Rugby Island Style: Paradise, Pacific People, and the Racialisation of Athletic Performance. Junctures: The Journal for Thematic Dialogue I 2 (June): 45-63.

Hage, Ghassan

2000 White Nation: Fantasies of White Supremacy in a Multicultural Society. New York: Routledge.

2003 Against Paranoid Nationalism: Searching for Hope in a Shrinking Society. Annandale, Nsw: Pluto Press.

Hands, David

2003 Pulling Power of All Blacks Under Question. The Times (London daily), I9 July.

Haynes, John

I996 From All Blacks to All Golds: New Zealand's Rugby League Pioneers. Christchurch: Ryan and Haynes.

Hoberman, John M

I997 Darwin's Athletes: How Sport Has Damaged Black America and Preserved the Myth of Race. Boston: Houghton Mifflin.

Hokowhitu, Brendan

2003a "Physical Beings": Stereotypes, Sport and the "Physical Education" of New Zealand Māori. Culture, Sport, Society 6 (2/3): I92-2 I 8.

2003 b Race Tactics: The Racialised Athletic Body. Junctures: The Journal For Thematic Dialogue I (December): 2 I-34.

2004 Tackling Māori Masculinity: A Colonial Genealogy of Savagery and Sport. The Contemporary Pacific I 6:259-284.

2005 Early Māori Rugby and the Formation of “Traditional” Māori Masculinity. Sporting Traditions 2I (2): 75-95.

2008 The Death Of Koro Paka: “Traditional” Māori Patriarchy. The Contemporary Pacific 20:I I 5-I4I.

2009 Māori Rugby and Subversion: Creativity, Domestication, Oppression and Decolonization. The International Journal of the History of Sport 26 (I2): 23 I4-2334.

Hokowhitu, Brendan, and Jay Scherer

2008 The Māori All Blacks and the Decentering of the White Subject: Hyperrace, Sport, and the Cultural Logic of Late Capitalism. Sociology of Sport Journal 25 (2): 243-262.

Hope, Wayne

2002 Whose All Blacks? Media, Culture and Society 24 (2): 235-253.

Huggan, Graham

2007 Australian Literature: Postcolonialism, Racism, Transnationalism.

New York: Oxford University Press.

Hyde, Tom

I993 White Men Can't Jump: The Polynesianisation of New Zealand Sport. Metro (NZ monthly magazine) I47 (September): 62-69. 
Jolly, Margaret

2008 Moving Masculinities: Memories and Bodies Across Oceania. The Contemporary Pacific 20:I-24.

Jones, Stephen

2004 Brown Is the New Black. Sunday Times (London), I August.

Knight, Lindsay

2007 The Commercial Threat to Rugby's Substance. Stuff.co.nz: Rugby Heaven, 2 I August. http://www.stuff.co.nz/sport/rugby/opinion/ columnists/lindsay-knight/49390 [accessed I 8 May 20Io]

Kusz, Kyle

2007 Revolt of the White Athlete: Race, Media and the Emergence of Extreme Athletes in America. New York: Peter Lang.

Laidlaw, Chris

I999 Rights of Passage: Beyond the New Zealand Identity Crisis. Auckland: Hodder Moa Beckett.

2002 Black and White. Dominion Post (Wellington daily), I9 July.

20I0 Somebody Stole My Game. Auckland: Hodder Moa.

Larner, Wendy

2006 Brokering Citizenship Claims: Neo-liberalism, Biculturalism and Multiculturalism in Aotearoa New Zealand. In Women, Migration, and Citizenship: Making Local, National, and Transnational Connections, edited by Evangelia Tastsoglou and Alexandra Dobrowolsky, I 3 I-I 48. Burlington, vT: Ashgate.

Liepins, Ruth

2000 Exploring Rurality Through "Community": Discourses, Practices and Spaces Shaping Australian and New Zealand Rural "Communities.” Journal of Rural Studies I6 (3): 325-34I.

Lipsitz, George

I998 The Possessive Investment in Whiteness: How White People Profit from Identity Politics. Philadelphia: Temple University Press.

Liu, James H, and Duncan Mills.

2006 Modern Racism and Neo-Liberal Globalization: The Discourses of Plausible Deniability and Their Multiple Functions. Journal of Community and Applied Social Psychology I 6:83-99.

Liu, James H, Marc Stewart Wilson, John McClure, and Te Ripowai Higgins

I999 Social Identity and the Perception of History: Cultural Representations of Aotearoa/New Zealand. European Journal of Social Psychology 29:IO2I-IO47.

MacLean, Malcolm

I999 Of Warriors and Blokes: The Problem of Māori Rugby for Pākehā Masculinity in New Zealand. In Making the Rugby World: Race, 
Gender, Commerce, edited by John Nauright and Timothy J L Chandler, I-26. London: Frank Cass.

Malarski, Paul

2009 Blackout Theory Under Scrutiny. The Mercury (Hobart daily), 23 October.

Matheson, John

200I What's The White Answer? New Zealand Rugby World (monthly magazine), October: 20-38.

McConahay, John B

I986 Modern Racism, Ambivalence, and the Modern Racism Scale. In Prejudice, Discrimination, and Racism, edited John F Dovidio and Samuel L Gaertner, 9I-I 25. New York: Academic Press.

McConahay, John B, Betty B Hardee, and Valerie Batts

I98 I Has Racism Declined in America? It Depends on Who is Asking and What is Asked. Journal of Conflict Resolution 25 (4): 563-579.

Merenstein, Beth Frankel

2008 Immigrants and Modern Racism: Reproducing Inequality. Boulder, CO: Lynne Rienner Publishers.

Miller, Toby, Geoffrey Lawrence, Jim McKay, and David Rowe 200 I Globalization and Sport: Playing the World. London: Sage.

Neal, Sarah, and Julian Agyeman, editors

2006 The New Countryside? Ethnicity, Nation and Exclusion in Contemporary Rural Britain. Bristol, uk: The Policy Press.

New Zealand Football (website of the national organizing body, based in Albany, Nz)

20I0 Inside NZF: Football in New Zealand. http://www.nzfootball.co.nz/ index.php? id=38 [accessed I 8 May 2010]

NZH, New Zealand Herald (Auckland daily)

2002 Editorial: Rugby Does Not Deserve Racial Slur. 20 July. http://www .nzherald.co.nz/nz/news/article.cfm?c_id= = \&objectid $=2098575$ [accessed I 8 May 2010]

2004a Editorial: Tackling Rugby's White Flight Head On. I3 August. http://www.nzherald.co.nz/nz/news/article.cfm?c_id=I \&objectid =3584I92 [accessed 4 May 2010]

2004b What's Eating Pākehā: The Verdict From the Street-We've Had Enough. New Zealand Herald, 2 I February.

Newton, Katherine

2009 Rugby Back in Vogue for Kiwi Children. Dominion Post (Wellington daily), I7 September.

Palmer, Farah

2007 Treaty Principles and Māori Sport: Contemporary Issues. In Sport in 
Aotearoa/New Zealand Society, 2nd edition, edited by Chris Collins and Steven J Jackson, 307-334. Melbourne: Thomson.

Panelli, Ruth, Deborah Allen, Brett Ellison, Anna Kelly, Alistair John, and Gail Tip

2008 Beyond Bluff Oysters? Place Identity and Ethnicity in a Peripheral Coastal Setting. Journal of Rural Studies 24 (I): 4I-55.

Panelli, Ruth, Phil Hubbard, Brad Coombes, and Sandie Suchet-Pearson

2009 De-centring White Ruralities: Ethnic Diversity, Racialisation and Indigenous Countrysides. Journal of Rural Studies 25 (4): 355-364.

Paul, Gregor

2004 Injury Fears Keep Whites out of Play. New Zealand Herald, I 4 August. http://www.nzherald.co.nz/nz/news/article.cfm?c_id= I \&objectid =3584I97 [accessed I 8 May 2010]

2007 Rugby: Pacifika Players Dominating Ranks. New Zealand Herald, 4 March. http://www.nzherald.co.nz/author/story.cfm?a_id=I96\& objectid=I0426898 [accessed 5 March 2007]

2009 Black Obsession: The All Blacks' Quest for World Cup Success. Auckland: Exisle Publishing.

Pearson, David

2000 The Ties that Unwind: Civic and Ethnic Imaginings in New Zealand. Nations and Nationalism 6 (I): 9I-I IO.

Perera, Suvendrini

I999 Whiteness and Its Discontents: Notes on Politics, Gender, Sex and Food in the Year of Hanson. Journal of Intercultural Studies 20:

Phillips, Jock I 83-I98.

I987 A Man's Country? The Image of the Pakeha Male-A History. Auckland: Penguin Books.

I999 The Hard Man: Rugby and the Formation of Male Identity in New Zealand. In Making Men: Rugby and Masculine Identity, edited by John Nauright and Timothy J L Chandler, 70-90. London: Frank Cass.

Puwar, Nirmal

2004 Space Invaders: Race, Gender and Bodies Out of Place. New York: Berg.

Rocchio, Vincent F

2000 Reel Racism: Confronting Hollywood's Construction of Afro-American Culture. Boulder: Westview Press.

Romanos, Joseph

2002 The Judas Game: The Betrayal of New Zealand Rugby. Wellington, NZ: Darius Press. 
Ropati, Tea

2006 Island Magic. Player (monthly magazine, Sunderland, Australia) October: 20-2I.

Ryan, Greg

200I Rural Myth and Urban Actuality: The Anatomy of All Black and New Zealand Rugby i 884-1938. New Zealand Journal of History 35 (I): 45-69.

2005 The End of an Aura: All Black Rugby and Rural Nostalgia in the Professional Era. In Tackling Rugby Myths: Rugby and New Zealand Society I854-2004, edited by Greg Ryan, I 5I-I72. Dunedin, NZ: University of Otago Press.

2008 Theatregoers in the Heartland: New Zealand Rugby and the Contradictions of Professionalism. In The Changing Face of Rugby: The Union Game and Professionalism Since 1995, edited by Greg Ryan, 4 I-62. Newcastle, uK: Cambridge Scholars Publishing.

Schech, Susanne B, and Jane Haggis

2000 Migrancy, Whiteness and the Settler Self in Contemporary Australia. In Race, Colour and Identity in Australia and New Zealand, edited by John Docker and Gerhard Fischer, 23 I-239. Sydney: University of New South Wales Press.

Smith, Adrian

2004 Black Against Gold: New Zealand-Australia Sporting Rivalry in the Modern Era. In Sport and National Identity in the Post-War World, edited by Adrian Smith and Dilwyn Porter, I68-I93. London: Routledge.

Souster, Mark

200I Mummy's Boys Turning their Backs on Rugby. The Times (London daily), 3 I October.

SPARC, Sport and Recreation New Zealand

2009 Sport and Recreation Profile: Rugby Union: Findings from the 2007/08 Active NZ Survey. Wellington, NZ: SPARC.

Statistics New Zealand

2010a QuickStats About Pacific Peoples: Location. Statistics New Zealand. http://www.stats.govt.nz/Census/2006censushomepage/Quickstats/ Quickstats-About-A-Subject/Pacific-Peoples/Location.Aspx [accessed I 8 May 20I0]

20Iob QuickStats About Pacific Peoples: Pacific Peoples Population. Statistics New Zealand. http://www.stats.govt.nz/Census/ 2006CensusHomePage/QuickStats/quickstats-about-a-subject/ pacific-peoples/pacific-people-population.aspx [accessed I8 May 2OIO] 
Stutchbury, Greg

20 Io Soccer-Cup a Financial Boost, But Sweeping Changes on CardsNZ. Reuters, UK edition, 30 April. http://uk.reuters.com/article/ idUKSGE63TooN20100430 [accessed 4 June 2010]

Sullivan, Shannon

2006 Revealing Whiteness: The Unconscious Habits of Racial Privilege. Bloomington, IN: Indiana University Press.

SST, Sunday Star-Times (Auckland)

2003 Junior Numbers Grow Despite “White Flight”" to Soccer. 25 May.

Taylor, Geoff

2007 We've Lost that Winning Feeling. Waikato Times (Hamilton daily),

Thomas, Paul 24 November.

2003 A Whole New Ball Game: Confronting the Myths and Realities of New Zealand Rugby. Auckland: Hodder Moa Beckett.

TV 3 (New Zealand)

2007 Parents Getting Kids into Rugby League. Campbell Live, Tv3, I7

Welham, Keri July.

2006 Seduced by the Beautiful Game. Dominion Post (Wellington daily),

Williams, Daniel I July.

200 I Pacific Beat: Islanders Rugby’s Biggest Winners. Time (weekly magazine), South Pacific edition, I 58 (I9), I 2 November, I6.

2008 Power Play. Time, South Pacific edition, 35 (8 September): 40-43.

Woods, Michael

2005 Rural Geography: Processes, Responses and Experiences in Rural Restructuring. London: Sage.

\section{Abstract}

This article examines postcolonial race politics and the re-centering of embodied whiteness and mediated white bodies as constituted through "white flight" and the so-called browning of rugby in New Zealand. Previous studies have problematized the ways in which rugby union is often framed within the national imaginary as a culturally unifying space-commonly depicted as transcendent of New Zealand's postcolonial racial tensions. Here we extend these critiques by pointing to several themes that have recently emerged within popular sports media, namely, those that position male Māori and Pacific Islander bodies as a threat to the well-being of the national game and the national identities it authorizes, and 
those that locate the Pākehā (white) male sporting body as under duress, or made vulnerable, by the brown-bodied, interloping "Other." The article concludes with a discussion of how these popular representations of racialized rugby-playing bodies, in the age of global mobility and national multiculturalism, articulate to and within foundational (white) national myths of white-settler meritocracy, rurality, and coloniality.

KEYWORDS: New Zealand, rugby, multiculturalism, postcolonialism, national identity 